\title{
PENDEKATAN BALANCE SCORECARD PADA LEMBAGA AMIL ZAKAT DI MASJID AGUNG JAWA TENGAH
}

\author{
Ari Kristin Prasetyoningrum
}

\begin{abstract}
Abstrak
Implementasi balanced scorecard dalam rangka revitalisasi Lembaga Pengelola Zakat menunju Good Organzation Governance pada LAZISMA Jawa Tengah belum dilaksanakan secara maksimal khususnya dalam perspektif kenangan. Sedangkan dari perspektif pelanggan yang didasarkan pada kepuasan pelanggan dalam menerima pelayanan dari lembaga cenderung baik karena sebagai organisasi sosial kemasyarakatan yang berdasarkan Islam mereka memperlakukan mustabik sebagai keluarga. Perspektif bisnis internal yang meliputi pembelajaran, kemampuan untuk berubah, penanganan keluhan pelanggan, waktu yang diperlukan untuk menangani keluban dan akuntabilitas organisasi juga dirasakan kurang karena bukan berorientasi profit, melainkan untuk. kepentingan ibadah. Perspektif pertumbuhan dan pembelajaran didasarkan pada pertumbuhan dan pembelajaran SDM (karyawan) didasarkan pada kepuasan karyawan sebagai human capital bagi organisasi menunjukkan bahwa karyawan yang dimiliki oleh lembaga zakat tersebut relatif masih dilandasi oleh faktor ibadah, loyalitas yang ditunjukean oleh karyawan dan usaha untuk belajar secara otodidak dilandasi untuk ibadah dan mencari ridha Allah SWT semata.
\end{abstract}

Keyword : balanced scorecard, lembaga zakat.

\section{Pendahuluan}

Indonesia merupakan salah satu negara yang memiliki penduduk beragama Islam terbesar di dunia. Penduduk Indonesia yang menurut data pertumbuhan yang dikeluarkan oleh Bank Dunia tahun 2012 berjumlah 244.775.796 jiwa dan $88 \%$ penduduknya mayoritas beragama Islam atau sekitar 182,570,000. jiwa, sehingga Indonesia termasuk dalam jumlah penduduk muslim terbesar di dunia. Jumlah penduduk muslim yang sangat besar merupakan salah satu potensi yang dapat dimanfaatkan oleh pemerintah untuk mengentaskan kemiskinan penduduk miskin yang telah mencapai 30,02 juta orang. (BPS tahun 2012). Oleh karena karena jumlah penduduk muslim 
Pendekatan Balance Scorecard pada LAZISMA

yang sangat besar, melalui salah satu instrumen keagamaan yaitu zakat dapat mengentaskan kemiskinan dan memperkecil kesenjangan sosial yang ada di masyarakat.

Zakat merupakan kewajiban agama yang harus dikeluarkan bagi umat muslim yang mampu sesuai dengan syariat agama Islam, zakat sebagai ibadah amaliyah yang menjurus ke aspek sosial, untuk mengatur kehidupan manusia dalam hubungannya dengan Allah dan dalam hubungan dengan sesama manusia. Sehingga zakat memiliki fungsi secara vertikal dan horizontal karena sebagai wujud ketaatan agama kepada Allah namun juga sebagai wujud kepedulian sosial untuk sesamanya.

Zakat merupakan salah satu dari rukun Islam dan lima nilai instrumental pengentas kemiskinan yang strategis dan berpengaruh pada tingkah laku ekonomi masyarakat sehingga tujuan zakat tidak hanya menyantuni secara konsumtif namun juga memiliki tujuan permanen untuk mengentaskan kemiskinan (Sasono, 1998). Oleh karena itu zakat harus dikelola secara produktif dan profesional agar zakat memiliki peranserta dalam mewujudkan cita-cita Islam menuju kehidupan umat yang sejahtera.

Pengelolaan Zakat telah lama dipraktekkan di Indonesia, namun dampaknya belum luas dirasakan oleh masyarakat. Potensi dana zakat filantropi Islam pada tahun 2011 menurut BAZNAS sebesar Rp. 217 trilyun (lihat tabel 1) belum mampu mengangkat kelompok miskin di negeri ini keluar dari kemiskinan. Terlepas dari keberadaan ratusan organisasi pengelola zakat (OPZ), baik Badan Amil Zakat (BAZ) maupun Lembaga Amil Zakat (LAZ). Namun kenyataan terkumpul dana zakat yang terkumpul hanya Rp. 2,1 trilyun atau $0.96 \%$ dari potensi. zakat (data dari LAZ maupun BAZ). Ini artinya bahwa faktor kepercayaan muzakki yang masih rendah terhadap pengelolaan zakat oleh lembaga pengelola zakat.

Tabel 1.1. Potensi Zakat Nasional

\begin{tabular}{lcccc}
\hline \multicolumn{2}{c}{ Keterangan } & $\begin{array}{c}\text { Potensi Zakat } \\
\text { (Rp. 000.000.000.000) }\end{array}$ & $\begin{array}{c}\text { Prosentase terhadap } \\
\text { PDB }\end{array}$ \\
\hline $\begin{array}{l}\text { Potensi } \\
\text { Tangga }\end{array}$ & Zakat & Rumah & 82,7 & $1,30 \%$ \\
$\begin{array}{l}\text { Potensi } \\
\text { Swasta }\end{array}$ & Zakat & Industri & 114,89 & $1,80 \%$ \\
\hline
\end{tabular}


Ari Kristin Prseryoningrum

\begin{tabular}{lcc}
\hline Potensi Zakat BUMN & 2,4 & $0,04 \%$ \\
Potensi Zakat Tabungan & 17 & $0,27 \%$ \\
Total Potensi Zakat & 217 & $3,40 \%$ \\
Nasional & & \\
\hline
\end{tabular}

Sumber : Riset BAZNAS dan FEM IPB (2011)

Berbagai upaya telah dilakukan untuk memperbaiki manajemen zakat oleh pemerintah dalam rangka meningkatkan transparansi dan akuntabilitas lembaga pengelola zakat baik melalui pembinaan, pengawasan dan pengelolan zakat, namun belum menunjukkan hasil yang optimal. Dikeluarkannya undangundang yang mengatur pengelolaan zakat antrara lain: (1) UU. No. 38 tahun 1999 Tentang Pengelolaan Zakat; (2) Keputudsan Menetri Agama Nomor 581 tahun 1999 tentang pelaksanaan UU No, 38 tahun 1999 tentang pengelolaan zakat serta (3) UU No. 23 tahun 2011 pengganti No. 38 tahun 1999 Tentang Pengelolaan Zakat. UU No. 23/2011 dibuat dalam rangka meningkatkan dayaguna dan hasil guna, zakat harus dikelola secara melembaga sesuai dengan syariat agama Islam yang bertujuan melakukan pengelolaan zakat. Pengelolaan yang dimaksud meliputi kegiatan perencanaan, pelaksanaan, dan pengordinasian dalam pengumpulan, pendistribusian, dan pendayagunaan zakat.

Oleh karena itu peneliti, mengembangkan model pengelolaan zakat dengan pendekatan balanced scorecard yang bersifat teknis, taktis, strategis dan operasional. Balanced Scorecard diciptakan untuk menetapkan goals dan sekaligus melakukan pengukuran atas pencapaiannya, sehingga secara tidak langsung dalam aplikasinya, sistem ini dapat dipakai sebagai alat penetapan strategi keuangan dan strategi manajerial koprehensip yang bersifat taknis teknis dan operasional dalam rangka revitalisasi Lembaga Pengelola Zakat yang amanah, profesional dan transparan.

Selama ini balanced scorecard (Kaplan, 1996) umumnya diimplementasikan pada perusahaan-perusahaan bisnis yang mempunyai sistem manajemen modern yang tersusun dalam perspektif pertumbuhan, proses bisnis internal, kepuasan dan keuangan menggambarkan keseimbangan ukuran finansial dan non finansial, antara indikator lagging dan indikator leading menjadi suatu sistem manajemen yang secara empiris telah banyak dipraktekkan pada perusahaan 
Pendekatan Balance Scorecard pada LAZISMA

bisnis dalam suatu kerangka kerja manajerial yang dikembangkan oleh peneliti dan diimplementasikan pada lembaga filantropi Islam termasuk LAZ.

Berdasarkan alasan memilih fokus penelitian dapat diperoleh suatu gambaran situasional, kondisional atas permasalahan yang dihadapi LAZ dalam pengelolaan zakat. balanced scorecard merupakan sistem manajemen yang sifatnya taktis, teknis, strategis dan oprasional. Oleh karena itu permasalahan penelitian adalah bagaimana implementasi balanced scorecard pada Lembaga Pengelola Zakat di Jawa Tengah dalam rangka menuju Good Organzation Governance.

Penelitian dilakukan pada Lembaga Pengelola Zakat yang beroperasi pada Lembaga Amil Zakat Infaq dan Shadaqah Masjid Agung (LAZISMA) Jawa Tengah. Tujuan penelitian ini adalah:

1. Mengidentifikasi balanced scorecard pada LAZISMA Jawa Tengah

2. Mengidentifikasi hambatan atau kendala implementasi balanced scorecard pada LAZISMA Jawa Tengah

3. Mengetahui kinerja LAZISMA Jawa Tengah berdasarkan perspektifperpektif balanced scorecard

4. Strategi peningkatan pengelolaan zakat dalam upaya good organization governance berdasarkan hasil penelitian

\section{Tinjauan Umum tentang Zakat}

Zakat adalah perintah Allah SWT yang dibebankan kepada kaum muslimin yang memenuhi syarat tertentu. Secara bahasa kata zakat mempunyai beberapa arti, yaitu keberkahan, pertumbuhan dan perkembangan, kesucian dan keberesan. Sedangkan secara istilah bahwa zakat adalah bagian dari harta dengan persyaratan tertentu yang diwajibkan Allah SWT kepada pemiliknya untuk diserahkan kepada yang berhak menerimanya dengan persyaratan tertentu pula. Ada benang merah yang dapat ditarik dari pengertian zakat baik secara bahasa dan istilah yaitu bahwa harta yang dikeluarkan zakatnya akan menjadi berkah, tumbuh, berkembang dan bertambah, suci dan baik. Dalam ayat yang lain Allah berfirman, "Dan sesuatu riba (tambahan) menambah pada sisi Allah. Dan apa yang kamu berikan berupa zakat yang kamu maksudkan untuk. 
Ari Kristin Prseryoningrum

mencapai keridhaan Allah, maka (yang berbuat demikian) itulah orang-orang yang melipat gandakan (pabalanya).”, QS. Ar-Ruum: 39.

Sesungguhnya maksud dan tujuan zakat adalah membangun kebersamaan, dengan tidak menjadikan segala perbedaan yang ada dalam masyarakat mengarah kepada kesenjangan sosial.

\section{Pengertian Zakat}

Zakat secara bahasa dalam kamus istilah fiqih berarti tumbuh, suci, baik, dan berkah. Zakat berarti pembersih (tazkiyyah) yakni pembersih terhadap jiwa.

Firman Allah dalam surat At Taubah ayat 103 :

Artinya : Ambillah zakat dari sebagian harta mereka, dengan itu kamu membersihkan dan mensucikan mereka dan mendoalah untuk mereka. Sesungguhnya doa kamu itu (menjadi) ketentraman jiwa bagi mereka. Dan Allah Maha Mendengar Lagi Maha Menetahui. (At Taubah : 103). ${ }^{1}$

Menurut istilah zakat mempunyai beberapa pengertian yang dapat penulis paparkan sebagai berikut :

1) Zakat menurut istilah agama Islam adalah kadar harta tertentu yang diberikan kepada yang berhak menerimanya, dengan beberapa syarat. ${ }^{2}$

2) Zakat adalah bagian harta yang wajib diberikan oleh setiap muslim yang memenuhi syarat kepada orang-orang tertentu. Syarat-syarat tertentu itu adalah nisab jumlah minimum harta yang dikeluarkan zakatnya. Haul (jangka waktu tertentu seseorang mengeluarkan zakat dari hartanya) dan kadarnya (ukuran besarnya zakat yang harus dikeluarkan). ${ }^{3}$

3) Zakat adalah suatu kewajiban Syar'i yang diwajibkan Islam atas umat Islam yang dipandang kaya. ${ }^{4}$

4) Dalam kitab Kifayatul Akhyar disebutkan :

\footnotetext{
${ }^{1}$ Departemen Agama RI, Al Quran dan Terjemahnya, Semarang: Toha Putra, 1999, hlm: 297-298.

2 Sulaiman Rasjid, Figh Islam (hukum fiqh Islam), Bandung: Penerbit Sinar BaruAlgensindo, 2007, hlm: 192.

${ }^{3}$ M. Daud Ali dan Habibah, Lembaga-Lembaga Islam di Indonesia, Jakarta; Raja Grafindo Persada, 1995, hlm : 241

${ }^{4}$ M. Abu Zahra, Membangun Masyarakat Islam, Jakarta: Pustaka Firdaus, hlm: 152
}

Volume VI/Edisi 1/Mei 2015 
Pendekatan Balance Scorecard pada LAZISMA

Artinya: Zakat menurut istilah adalah nama untuk ukuran harta tertentu yang diberikan pada golongan tertentu dengan beberapa syarat. ${ }^{5}$

5) Zakat disebut juga infaq karena hakekatnya zakat adalah penyerahan harta untuk kebijakan-kebijakan yang diperintahkan Allah SWT. Zakat disebut shadaqah karena salah satu tujuan utama zakat adalah untuk mendekatkan diri (taqarrub) kepada Allah SWT. Zakat disebut hak karena merupakan ketetapan yang bersifat pasti dari Allah SWT yang harus diberikan kepada mereka yang berhak menerimanya (mustabiq). ${ }^{6}$

\section{Jenis-Jenis Zakat}

Zakat dibedakan dalam dua kelompok yaitu:

1. Zakat fitrah

Zakat fitrah merupakan zakat jiwa (zakah al-nafs) yaitu kewajiban berzakat bagi setiap individu baik untuk orang yang sudah dewasa maupun belum dewasa dan dibarengi dengan ibadah puasa (shaum).

2. Zakat mal (harta/kekayaan)

Zakat mal adalah zakat kekayaan, artinya zakat yang dikeluarkan dari kekayaan atau sumber kekayaan itu sendiri. Uang adalah kekayaan. Pendapatan dari profesi, usaha, investasi merupakan sumber dari kekayaan. ${ }^{7}$

\section{Landasan Hukum Zakat}

Zakat merupakan satu pilar dalam pembangunan ekonomi Islam, yang merupakan sumber dana potensial bagi upaya membangun kesejahteraan umat Islam. Diwajibkannya zakat bagi umat Islam itu didasarkan pada sumbersumber hukum Islam yaitu Al-Quran, sunnah, maupun ijma’ para ulama.

a. Al-Quran, ayat yang memerintahkan mengeluarkan zakat antara lain: 1) At Taubah ayat 103; 2) Al Muzammil ayat 20; dan 3) Al Baqoroh ayat 43

b. Sunnah

${ }^{5}$ Abu Baqir Ibnu Muhammad Al Khusaini, Kifayatul Akbyar Juz 1, Surabaya, t,th, hlm : 172

${ }^{6}$ Didin Hafidhuddin, Zakat Dalam Perekonomian Modern, Jakarta: Gema Insani, 2002, hlm: 9

${ }^{7}$ Mursyidi, Op. Cit, hlm: 77-80 
Artinya : Diceritakan dari Abdillah bin Muazh bercerita Asham ibnu Muhammad bin Zaidh bin Umar dari Bapaknya Abdullah berkata bahwa Rosulullah SAW bersabda : Islam dibangun atas 5 tiang pokok yaitu kesaksian bahwa tiada tuhan selain Allah dan sesungguhnya Muhammad adalah hamba dan RosulNYA, mendirikan shalat, membayar zakat, mengunjungi rumah Allah (berhaji) dan puasa Ramadhan. ${ }^{8}$

c. Ijma' Ulama, ialah adanya kesepakatan semua (ulama) umat Islam disemua Negara kesepakatanya bahwa zakat adalah wajib. ${ }^{?}$

\section{Syarat Zakat}

Zakat merupakan hak Allah yang dikeluarkan oleh setiap muslim yang diberikan kepada delapan golongan mustabiq dengan mengharap keberkahan dan kesucian jiwa. Zakat mempunyai beberapa syarat wajib dan syarat sah. Syarat wajib zakat adalah merdeka, muslim, kepemilikan harta yang penuh, mencapai nisab, dan mencapai haul. Adapun syarat sahnya zakat adalah niat yang menyertai pelaksanaan zakat. Syarat-syarat zakat yang harus dipenuhi seorang muslim adalah: Merdeka, Islam, Harta yang dikeluarkan adalah harta yang wajib dizakati, Harta yang dizakati telah mencapai nisab atau senilai dengannya, Kepemilikan harta telah mencapai setahun (haul), dan Milik yang sempurna.

\section{Hikmah Zakat}

Kesenjangan penghasilan rezeki dan mata pencarian dikalangan manusia merupakan kenyataan yang tidak bisa dipungkiri. ${ }^{10}$ Zakat memiliki kedudukan yang sangat penting, hal ini dapat dilihat dari hikmah zakat dalam meningkatkan harkat dan martabat manusia.

Hikmah zakat antara lain sebagai berikut:

\footnotetext{
${ }^{8}$ Imam Muslim, Shakhib Muslim Juz I, Semarang; Thoha Putra, t,th, hlm : 26-27

${ }^{9}$ Wahbah Al-Zuhayly, Al Fiqh Al Islami Wa'adillah, Terjemah: Agus Effendi dan Bahruddin Fannany, Zakat Kajian Berbagai Mazhab, Bandung: PT Remaja Rosdakarya, Cet. 1, 1995, hlm: 90

${ }^{10}$ Wahbah Al-Zuhayly, Op. Cit, hlm: 85
} 
Pendekatan Balance Scorecard pada LAZISMA

a. Sebagai perwujudan keimanan kepada Allah SWT

b. Membersihkan dan mengikis akhlak yang buruk

c. Alat pembersih harta dan penjagaan dari ketamakan orang jahat

d. Ungkapan rasa syukur atas nikmat yang Allah berikan.

e. Untuk pengembangan potensi umat

f. Dukungan moral kepada orang yang baru masuk Islam

g. Menambah pendapatan negara untuk proyek-proyek yang berguna bagi umat

h. Menolong, membantu, membina dan membangun kaum dhuafa' yang lemah dengan materi sekedar untuk memenuhi kebutuhan pokok hidupnya.

i. Memberantas penyakit iri hati, rasa benci dan dengki dari diri orangorang miskin yang tidak memiliki apa-apa dan tidak ada uluran tangan kepada mereka, sementara di sekitarnya orang-orang kaya berkehidupan cukup, apalagi mewah.

j. Menjadi unsur penting dalam mewujudkan keseimbangan distribusi harta (social distribution), dan keseimbangan tanggung jawab individu dalam masyarakat.

k. Dapat menunjang terwujudnya sistem kemasyarakatan Islam yang berdiri atas prinsip-prinsip : ummatan wahidah (umat yang satu), musawah (persamaan derajat, hak dan kewajiban), ukhuwah Islamiyah (persaudaraan Islam), dan takaful ijtima' (tanggung jawab bersama).

1. Dapat mensucikan diri (pribadi) dari kotoran dosa, memurnikan jiwa (menumbuhkan akhlak mulia menjadi murah hati, peka terhadap rasa kemanusiaan) dan mengikis sifat bakhil (kikir) serta serakah. Dengan begitu akhirnya tercapai suasana ketenangan batin karena terbebas dari tuntutan Allah dan kewajiban kemasyarakatan.

m. Dari sisi pembangunan kesejahteraan umat, zakat merupakan salah satu instrument pemerataan pendapatan. Apabila zakat dikelola dengan baik mungkin pertumbuhan ekonomi masyarakat akan membaik sekaligus menjadikan pemerataan pendapatan lebih teratur. ${ }^{11}$

${ }^{11}$ Heri Sudarsono, Bank dan Lembaga Kenangan Syariab Deskripsi dan Ilustrasi, Yogyakarta : EKONISIA, cet.2, 2004, hlm : 237-238 


\section{Strategi Dalam Penghimpunan Dana Zakat}

Sumber zakat dapat diperoleh dari (a) hasil tumbuh-tumbuhan atau tanaman yang bernilai ekonomis, seperti misalnya anggrek, rambutan, durian, pepaya dan sebagainya, (b) hasil peternakan dan perikanan seperti ayam, hasil empang, hasil laut dan sebagainya, (c) harta kekayaan dalam semua bentuk badan usaha, baik yang dimiliki oleh perorangan maupun bersma-sama dengan orang lain, (d) hasil penyewaan atau pengontrakan rumah, bangunan, tanah, kendaraan dan sebagainya, (e) pendapatan yang diperoleh dari sumber lain. ${ }^{12}$ Strategi dalam pengumpulan dana zakat dapat dilakukan dengan berbagai macam cara diantaranya:

1. Spanduk kampanye zakat

2. Media periklanan, seperti: televisi, radio, dan surat kabar

3. Datang langsung ke mu₹akki zakat

4. Jemput bola, maksud dari jemput bola, murakki telfon ke petugas amil zakat yang nantinya petugas amil datang untuk menghitung dan mengambil zakat

5. Transfer rekening bank

6. Lewat sms, misal: dengan mengetik zakat (spasi) pkpu (spasi) Jateng dan mengirimnya ke $92528 .{ }^{13}$

\section{Organisasi Pengelola Zakat}

Dalam menyalurkan zakat dianjurkan melalui organisasi pengelola zakat. Hal tersebut sesuai dengan Al-Qur'an. Amil zakat merupakan perantara antara seseorang yang ingin berzakat dengan mereka yang berhak mendapat zakat. Dengan adanya UU No. 38 tahun 1999 tentang pengelolaan zakat, memberi peluang besar untuk pengelolaan zakat oleh Badan atau Lembaga Amil Zakat secara profesional. Dengan adanya UU tersebut saat ini bermunculan organisasi pengumpul zakat (Amil Zakat), seperti Dompet Dhuafa, Rumah Zakat Indonesia, Dompet Peduli Ummat (DPU) Darut Tauhid, dan lain-lain.

\footnotetext{
12 Mohammad Daud Ali, Sistem Ekonomi Islam Zakat dan wakaf, Jakarta: Penerbit Universitas Indonesia (UI-Press), 1988, hlm: 67

${ }^{13}$ www. suaramerdeka.com/harian. Hari Selasa, 1 Juli 2008, jam 09.00 WIB
}

Volume VI/Edisi 1/Mei 2015 
Di Indonesia, organisasi pengelola zakat ada yang bersifat formal dan informal. Organisasi yang bersifat formal adalah yang dibentuk oleh pemerintah maupun lembaga yang dibentuk oleh masyarakat, dikukuhkan dan dilindungi oleh pemerintah. Sedangkan organisasi yang bersifat informal adalah organisasi pengelola zakat yang dibentuk oleh masyarakat tetapi tidak ada campur tangan dari pemerintah, seperti yayasan-yayasan dan masjid-masjid sekitar tempat tinggal yang dipercaya oleh masyarakat setempat untuk mengelola zakat yang meliputi pengumpulan, pendistribusian, dan pendayagunaan zakat. Selain itu dikatakan informal jika zakat disalurkan langsung kepada para mustabik. Badan Amil Zakat (BAZ) adalah suatu organisasi pengelola zakat yang didirikan oleh pemerintah terdiri dari unsur masyarakat dan pemerintah dengan tugas mengumpulkan, mendayagunakan dan mendistribusikan zakat sesuai dengan ketentuan agama (DEPAG, 2005). BAZ bekerja dalam tingkat Nasional (BAZNAS), Propinsi (BAZDA), tingkat kabupaten/kota, dan tingkat kecamatan.

\section{Balanced Scorecard}

Konsep Balanced Scorecard adalah pendekatan terhadap strategi manajemen yang dikembangkan oleh Drs.Robert Kaplan (Harvard Business School) and David Norton pada awal tahun 1990. Balanced Scorecard berasal dari dua kata yaitu balanced (berimbang) dan scorecard (kartu skor). Balanced (berimbang) berarti adanya keseimbangan antara performance keuangan dan nonkeuangan, performance jangka pendek dan performance jangka panjang, antara performance yang bersifat internal dan performance yang bersifat eksternal. Sedangkan scorecard (kartu skor) yaitu kartu yang digunakan untuk mencatat skor performance seseorang. Kartu skor juga dapat digunakan untuk merencanakan skor yang hendak diwujudkan oleh seseorang di masa depan.

Mula-mula Balanced Scorecard digunakan untuk memperbaiki sistem pengukuran kinerja eksekutif. Awal penggunaannya kinerja eksekutif diukur hanya dari segi keuangan. Kemudian berkembang menjadi luas yaitu empat perspektif, yang kemudian digunakan untuk mengukur kinerja organisasi secara utuh. Empat perspektif tersebut yaitu keuangan, pelanggan, proses bisnis internal serta pembelajaran dan pertumbuhan. 
Balanced Scorecard adalah suatu mekanisme sistem manajemen yang mampu menerjemahkan visi dan strategi organisasi ke dalam tindakan nyata di lapangan. Balanced Scorecard adalah salah satu alat manajemen yang telah terbukti telah membantu banyak perusahaan dalam mengimplementasikan strategi bisnisnya.

Menurut Atkinson, Banker, Kaplan and Young (1997) Balance Scorecard adalah: Suatu set dari target dan hasil kinerja yang digunakan sebagai pendekatan untuk mengukur kinerja yang diarahkan kepada gabungan faktor kritis dari tujuan organisasi." Sedangkan Anthony and Govindarajan (1997): menyatakan bahwa Balance Scorecard merupakan suatu alat sistem untuk memfokuskan perusahaan, meningkatkan komunikasi antar tingkatan manjemen, menentukan tujuan organisasi dan memberikan umpan balik yang terus-menerus guna keputusan yang strategis. Dari uraian diatas maka, ciri-ciri sistem balance score card, mengandung unsur-unsur sebagai berikut: (1) merupakan suatu aspek dari strategi perusahaan, (2) menetapkan ukuran kinerja melalui mekanisme komunikasi antar tingkatan manajemen dan (3) mengevaluasi hasil kinerja secara terus menerus guna perbaikan pengukuran kinerja pada kesempatan selanjutnya. Setiap ukuran dalam balance scorecard menyajikan suatu aspek dari strategi perusahaan, karena dengan sistem ini manajemen dapat menggunakannya untuk berbagai alternatif pengukuran terhadap hal-hal berikut: (1) Faktor-faktor kritis yang menentukan keberhasilan strategi perusahaan (2) Menunjukan hubungan individu/sub bisnis unit dengan yang dihasilkannya, sebagai akibat dari penetapan pengukuran yang telah dikomunikasikannya (3) Menunjukan bagaimana pengukuran nonfinansial mempengaruhi finansial jangka panjang dan (4) Memberikan gambaran luas tentang perusahaan yang sedang berjalan.

Balanced scorecard merupakan sistem manajemen strategis yang menterjemahkan visi dan strategi suatu organisasi kedalam tujuan dan ukuran operasional (Hansen dan Mowen 2003). Tujuan dan ukuran operasional tersebut kemudian dinyatakan dalam empat perspektif yaitu perspektif finansial, pelanggan (customers), proses bisnis internal (internal business process), serta pembelajaran dan pertumbuhan (learning and growth) (Kaplan dan Norton 1996). Perspektif finansial menggambarkan keberhasilan finansial yang dicapai oleh organisasi atas aktivitas yang dilakukan dalam 3 perspektif lainnya. 
Pendekatan Balance Scorecard pada LAZISMA

Perspektif pelanggan menggambarkan pelanggan dan segmen pasar dimana organisasi berkompetisi. Perspektif proses bisnis internal mengidentifikasikan proses-proses yang penting untuk melayani pelanggan dan pemilik organisasi. Perspektif pembelajaran dan pertumbuhan menggambarkan kemampuan organisasi untuk menciptakan pertumbuhan jangka panjang. Balanced scorecard sebagai suatu kerangka kerja atau sistem manajemen yang mengintegrasikan visi, strategi dan keempat perspektif secara seimbang ditunjukkan dalam gambar berikut:

\section{Gambar Kerangka Kerja Balanced Scorecard}

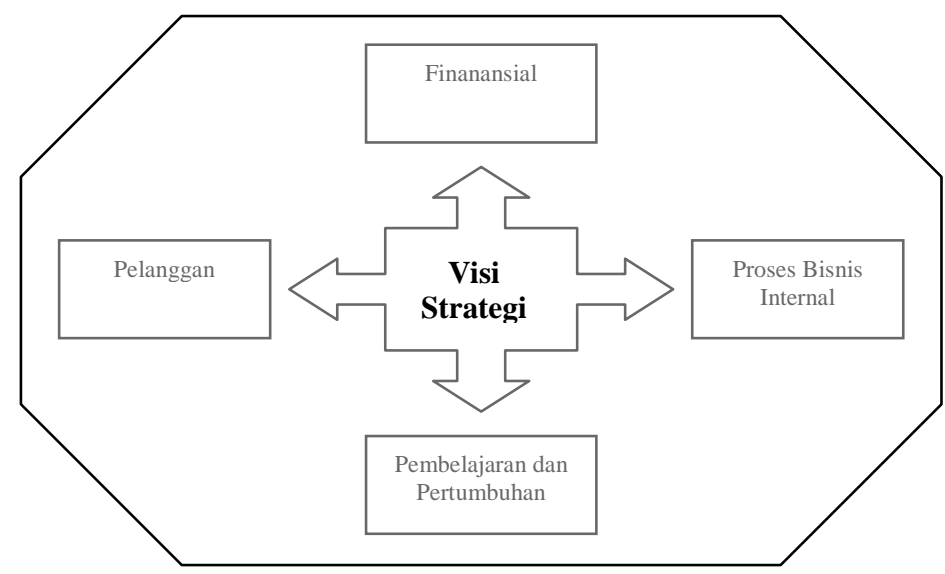

Sumber: Robert S Kaplan dan David P Norton: Using the Balanced Scorecard as a Startegic Management System: Harvard Busines Review (Januari-Pebruari, 1996)

\section{Keunggulan Balanced Scorecard}

Dalam perkembangannya Balanced scorecard telah banyak membantu perusahaan untuk sukses mencapai tujuannya. Balanced scorecard memiliki beberapa keunggulan yang tidak dimiliki sistem strategi manajemen tradisional. Strategi manajemen tradisional hanya mengukur kinerja organisasi dari sisi keuangan saja dan lebih menitik beratkan pengukuran pada hal-hal yang bersifat tangible, namun perkembangan bisnis menuntut untuk mengubah pandangan bahwa hal-hal intangible juga berperan dalam kemajuan organisasi. Balanced scorecard menjawab kebutuhan tersebut melalui sistem manajemen strategi kontemporer, yang terdiri dari empat perspektif yaitu: keuangan, pelanggan, proses bisnis internal serta pembelajaran dan pertumbuhan. 
Keunggulan pendekatan Balanced scorecard dalam sistem perencanaan strategis (Mulyadi, 2001, p.18) adalah mampu menghasilkan rencana strategis, yang memiliki karakteristik sebagai berikut (1) komprehensif, (2) koheren, (3) seimbang dan (4) terukur.

\section{Implementasi Balanced Scorecard}

Langkah pertama dalam mengimplementasikan balanced scorecard adalah melakukan identifikasi data yang diperlukan untuk mengimplementasikan balanced scorecard. Selanjutnya menentukan teknologi informasi yang digunakan untuk memudahkan proses mengkomunikasikan balanced scorecard. Implementasi dari balance scorecard harus dilakukan secara bertahap. Langkah kedua adalah membangun scorecard secara menyeluruh. Pada awalnya balanced scorecard dibuat pada tingkat organisasi, yang kemudian diterjemahkan kedalam balanced scorecard unit-unit dalam organisasi, diterjemahkan lagi kedalam balanced scorecard departemen, dan yang terakhir adalah balanced scorecard tim atau individu. Langkah ketiga adalah menggunakan data scorecard untuk evaluasi dan peningkatan. Pada tahapan ini terjadi arus informasi dari setiap tim atau individu kepada departemen, yang oleh departemen dilanjutkan ke unit organisasi, yang akhirnya semua informasi dikumpulkan pada tingkat organisasi (Imelda, $2004: 120)$

Kajian yang dilakukan Linge dan Schimann (1996), terhadap perusahaan tentang pengukuran perusahaan, menyatakan bahwa $76 \%$ meliputi pengukuran finansial, pelaksanaan dan kepuasan pelanggan., sedangkan sisanya $23 \%$ merupakan pengukuran innovasi dan perubahan manajemen. Pengukuran kinerja finansial masih dianggap yang paling, hal ini dapat mendorong innovasi dan perubahan, akan terkait dengan kompensasi penting, sebesar $25 \%$. Tetapi kepuasan pelanggan merupakan prioritas, sebesar $79 \%$, dan perusahaan memberi respon yang serius dan mengangap informasi ini sangat berharga.

Dalam penelitian Nomura Research Institute (NRI) Papers No. 45, 1 April 2002 dikemukakan bahwa Jepang sudah beberapa tahun lalu mengintroduksikan pola kerja balance scorecard (Balanced Scorecard) terhadap lebih dari 20 perusahaan (Morisawa, 2002:3). Dari hasil penelitiannya, NRI dapat memberi kesimpulan bahwa berdasarkan pengalaman-pengalaman perusahaan 
Pendekatan Balance Scorecard pada LAZISMA

yang menerapkan pengukuran kinerja dengan balanced scorecard tersebut merasakan bahwa balanced scorecard memang memiliki keunggulan yang dirangkum menjadi lima point sebagai berikut: (1) Balanced scorecard dapat digunakan untuk melakukan perbaikan keseimbangan di antara sasaran-sasaran jangka pendek, jangka menengah, dan jangka panjang, (2) Dapat menciptakan pemahaman strategi perubahan dengan menyusun atau menetapkan indikatorindikator non-finansial kuantitatif disamping indikator-indikator financial, (3) Mengurangi keragu-raguan atau kekaburan dengan tetap menjaga indikatorindikator non finansial kuantitatif (4) Mempromosikan proses pembelajaran organisasi melalui suatu pengulangan siklus hipotesis verifikasi dan (5) Memperbaiki platform strategi komunikasi secara umum dalam organisasi yang mencerminkan keterkaitan antara pimpinan dan bawahan. NRI mengemukakan salah satu contoh kasus yang spektakuler tentang keberhasilan penerapan Balanced scorecard yang berimplikasi pada perbaikan kinerja perusahaan.

Murphy and Russel (2002:2) menemukan bahwa penggunaan Balanced Scorecard dapat menggantikan Costumer Relationship Management (CRM) Strategi, yakni suatu strategi dimana perusahaan mencoba mengelola hubungan yang baik dengan para pelanggan untuk menciptakan nilai tambah untuk para pelanggan dan untuk perusahaan itu sendiri. Hal ini ditunjukkan bahwa lebih dari setengah proyek-proyek CRM tidak menghasilkan nilai tambah apapun bagi perusahaan, dan 50\% dari CRM Strategy tetap saja mengalami kegagalan dalam penerapannya di dunia bisnis, namun Balanced Scorecard dapat menggantikannya.

\section{Kajian Riset Sebelumnya}

Dari hasil survey terhadap beberapa penelitian seputar zakat, secara umum dapat disimpulkan bahwa maju dan berkembang dengan pengelolaan zakat dapat memberikan kontribusi yang signifikan terhadap pembangunan sosial dan ekonomi. Beberapa penelitian terdahulu tentang zakat dapat dilihat pada tabel berikut: 
Tabel Penelitian Terdahulu

\begin{tabular}{|c|c|c|c|c|c|}
\hline No & $\begin{array}{l}\text { Nama } \\
\text { Peneliti }\end{array}$ & Judul & $\begin{array}{c}\text { Metode } \\
\text { Penelitian }\end{array}$ & $\begin{array}{c}\text { Tempat } \\
\text { penelitian }\end{array}$ & Kesimpulan \\
\hline 1 & $\begin{array}{l}\text { Emmy } \\
\text { Hamidiyah } \\
(2004)\end{array}$ & $\begin{array}{l}\text { Analisis faktor- } \\
\text { faktor yang } \\
\text { mempengaruhi } \\
\text { pengumpulan } \\
\text { zakat, infak, } \\
\text { sedekah wakaf } \\
\text { pada lembaga } \\
\text { pengelola zakat } \\
\text { (studi kasus: } \\
\text { dompet dhuafa } \\
\text { republika) }\end{array}$ & $\begin{array}{l}\text { Kuantitatif, } \\
\text { Survey, Analisis } \\
\text { Faktor }\end{array}$ & $\begin{array}{l}\text { Dompet } \\
\text { Duafa } \\
\text { Republika, } \\
\text { Muzakki }\end{array}$ & $\begin{array}{l}\text { Faktor-faktor yang } \\
\text { diteliti meliputi biaya } \\
\text { promosi, jaringan, } \\
\text { regulasi dan moment } \\
\text { bulan ramadhan } \\
\text { berpengaruh } 75.5 \% \\
\text { atas pengumpulan } \\
\text { ZISWK }\end{array}$ \\
\hline 2 & $\begin{array}{l}\text { Husnul } \\
\text { Khatimah } \\
\text { (2004) }\end{array}$ & $\begin{array}{l}\text { Pengaruh Zakat } \\
\text { Produktif } \\
\text { Terhadap } \\
\text { Peningkatan } \\
\text { Kesejahteraan } \\
\text { Ekonomi Para } \\
\text { Mustahik }\end{array}$ & $\begin{array}{l}\text { Kuantitatif, } \\
\text { Regresi }\end{array}$ & $\begin{array}{l}\text { Dompet } \\
\text { Dhuafa } \\
\text { Republika, } \\
\text { Mustahik }\end{array}$ & $\begin{array}{l}\text { Program pembiayaan } \\
\text { baik melaui skim } \\
\text { maupun pembiayaan } \\
\text { bagi hasil terbukti } \\
\text { memberikan manfaat } \\
\text { bagi kemampuan } \\
\text { berusaha }\end{array}$ \\
\hline 3 & $\begin{array}{l}\text { Agus } \\
\text { Lukman } \\
\text { Hakim } \\
(2004)\end{array}$ & $\begin{array}{l}\text { Persepsi } \\
\text { Karyawan dan } \\
\text { Relawan } \\
\text { terhadap } \\
\text { Efektifitas } \\
\text { Aspek-Aspek } \\
\text { Organisasi } \\
\text { Pengelolaan } \\
\text { Zakat dalam } \\
\text { Pendistribusian } \\
\text { ZIS }\end{array}$ & Survey & $\begin{array}{l}\text { Rumah } \\
\text { Zakat } \\
\text { Indonesia, } \\
\text { Amil }\end{array}$ & $\begin{array}{l}\text { Aspek-aspek } \\
\text { organisasi RZI } \\
\text { cabang Jakarta dan } \\
\text { pelaksanaan program } \\
\text { pelayanan dinilai } \\
\text { positif oleh para } \\
\text { responden (relawan- } \\
\text { amil) }\end{array}$ \\
\hline 4 & $\begin{array}{l}\text { Umrotul } \\
\text { Khasanah } \\
(2003)\end{array}$ & $\begin{array}{l}\text { Analisis Model } \\
\text { Pengelolaan } \\
\text { Dana Zakat di } \\
\text { Indonesia } \\
\text { (Kajian terhadap } \\
\text { BAZ dan LAZ) }\end{array}$ & $\begin{array}{l}\text { Deskriptif, } \\
\text { wawancara }\end{array}$ & $\begin{array}{l}11 \quad \text { LAZ } \\
\text { Nasional } \\
\text { dan } 2 \\
\text { BAZ }\end{array}$ & $\begin{array}{l}\text { Klasifikasi, sifat, } \\
\text { struktur organisasi } \\
\text { dari Amil Zakat yang } \\
\text { berbeda-beda. }\end{array}$ \\
\hline
\end{tabular}


Pendekatan Balance Scorecard pada LAZISMA

\begin{tabular}{|c|c|c|c|c|c|}
\hline No & $\begin{array}{c}\text { Nama } \\
\text { Peneliti }\end{array}$ & Judul & $\begin{array}{c}\text { Metode } \\
\text { Penelitian }\end{array}$ & $\begin{array}{l}\text { Tempat } \\
\text { penelitian }\end{array}$ & Kesimpulan \\
\hline 5 & $\begin{array}{l}\text { Muhammad } \\
\text { Yusrizal } \\
(2002)\end{array}$ & $\begin{array}{l}\text { Manajemen } \\
\text { Zakat Infak dan } \\
\text { Sedekah }\end{array}$ & $\begin{array}{l}\text { Kualitatif, } \\
\text { pengamatan- } \\
\text { wawancara } \\
\text { mendalam }\end{array}$ & $\begin{array}{l}\text { Dompet } \\
\text { Dhuafa } \\
\text { Republika, } \\
\text { Amil }\end{array}$ & $\begin{array}{l}\text { UU No.38 tahun } \\
1999 \text { memberikan } \\
\text { kekuatan hukum bagi } \\
\text { Dompet Duafa untuk } \\
\text { menjalankan } \\
\text { peranannya lebih baik } \\
\text { dalam usaha } \\
\text { pengentasan } \\
\text { kemisiknan }\end{array}$ \\
\hline 6 & $\begin{array}{l}\text { Mashudi } \\
\text { (2012) }\end{array}$ & $\begin{array}{l}\text { Evaluasi } \\
\text { Pengelolaan } \\
\text { Zakat di } \\
\text { Indonesia }\end{array}$ & Literatur & $\begin{array}{l}\text { LAZ di } \\
\text { Indonesia }\end{array}$ & $\begin{array}{l}\text { Banyaknya lembaga } \\
\text { amil zakat yang } \\
\text { berdiri, kesadaran } \\
\text { masyarakat untuk } \\
\text { membayar zakat yang } \\
\text { terus meningkat, } \\
\text { namun fenomena ini } \\
\text { menyisakan } \\
\text { permasalahan bagi } \\
\text { pengelolaan zakat, } \\
\text { karena lembaga- } \\
\text { lembaga zakat berdiri } \\
\text { cenderung } \\
\text { independen dan } \\
\text { mencanangkan } \\
\text { program masing- } \\
\text { masing yang lemah } \\
\text { membangun } \\
\text { koordinasi dan sinergi } \\
\text { antar satu lembaga } \\
\text { dengan lembaga } \\
\text { lainnya. Sehingga } \\
\text { muncul wacana, zakat } \\
\text { dikelola oleh negara } \\
\text { agar } \\
\text { penayagunaaannya } \\
\text { lebih efektif. }\end{array}$ \\
\hline
\end{tabular}




\section{Kerangka Pemikiran Teoritis}

Kesadaran akan pentingnya merealisasi dan menumbuhkan kesadaran untuk membayar zakat mendorong tumbuhnya LAZ, namun sebagian besar pengelolaannya belum dilakukan secara optimal. Bahkan cenderung memiliki citra yang kurang profesional, karena LAZ dipandang sebagai lembaga gressroot yang tidak amanah dan profesional. Akibatnya kepercayaan muzaki untuk menyalurkan dananya ke LAZ sangat rendah. Oleh karena itu diperlukan meningkatkan pengelolaan zakat yang amanah, profesional dan transparan dengan balanced scorecard dalam upaya upaya good orgnization governance. Oleh karena itu, maka kerangka berpikir dalam penelitian dijelaskan pada gambar dibawah ini:

\section{Gambar Kerangka Pemikiran Teoritis}

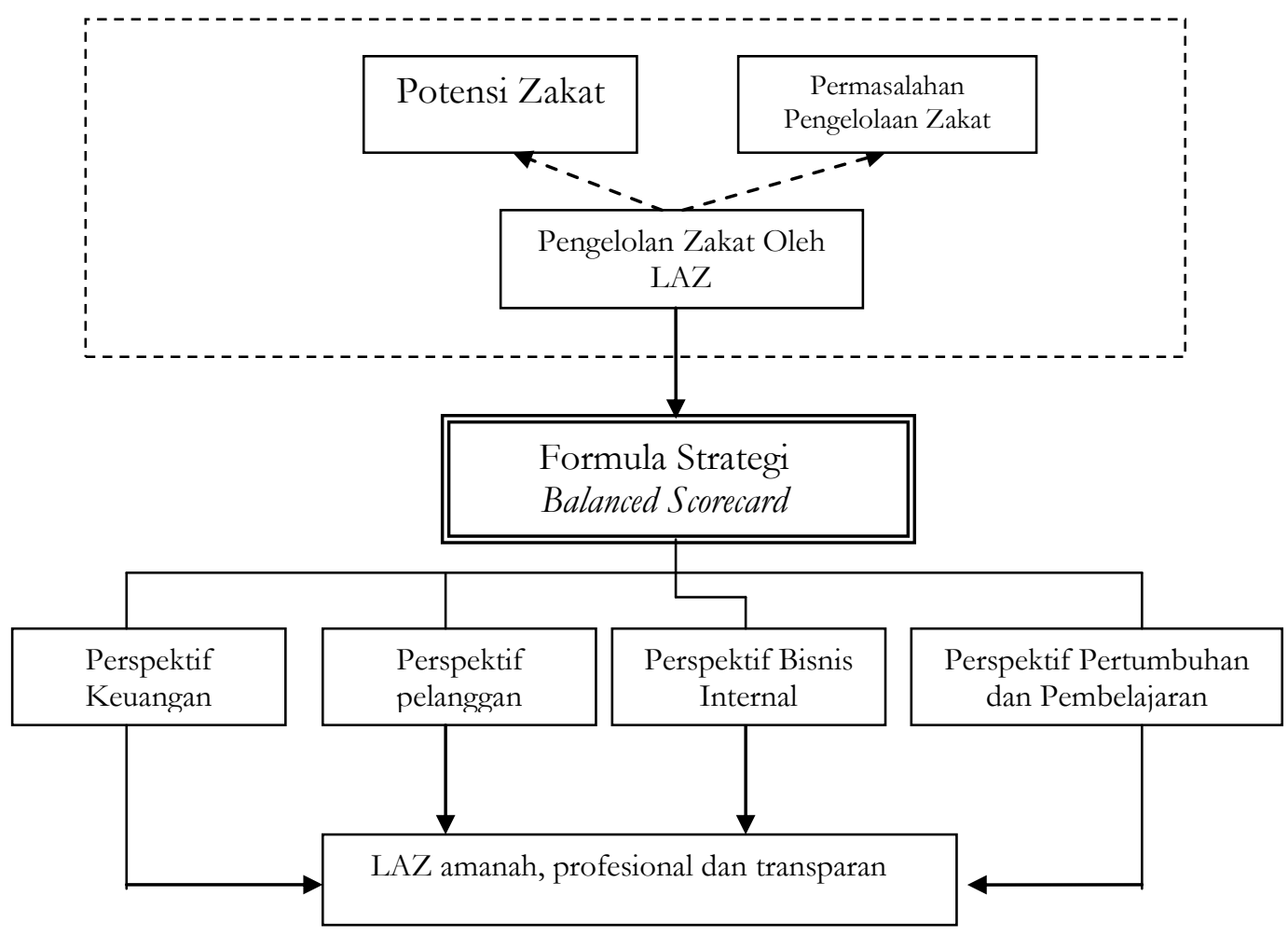

Sumber: Dikembangkan untuk penelitian 
Pendekatan Balance Scorecard pada LAZISMA

\section{Metodologi Penelitian}

Penelitian ini merupakan penelitian kebijakan yang menggunakan pendekatan kualitatif dan kuantitatif. Metode ini digunakan untuk memperoleh data perkembangan pengelolaan dan pendistribusian zakat, (3) kuesioner yang disebarkan ke karyawan, Murakki maupun Mustabik dan (4) Dokumentasi, yang menjadi sumber-sumber data adalah sejumlah dokumen tertulis objek penelitian.

Data dalam penelitian ini terdiri dari data primer dan data sekunder. Data primer diperoleh dengan cara (1) Observasi, teknik ini digunakan untuk mengamati obyek observasi dalam pengelolaan zakat, (2) Wawancara dan Kuesioner untuk memperoleh informasi dari para pengelolah Zakat, Karyawan, Muzakki maupun Mustabik yang ditentukan sebagai reponden. Sedangkan data sekunder diperoleh dengan melakukan studi kepustakaan dengan mempelajari buku-buku, kajian ilmiah dan dokumen-dokumen dari laporan pengelolaan zakat lembaga yang bersangkutan

Objek penelitian adalah balanced scorecard pada Lembaga Amil Zakat Infaq dan Shadaqah Masjid Agung (LAZISMA) Jawa Tengah, sedangkan pengelola, karyawan, murakki dan mustabik adalah unit yang dianalisis. Pemilihan responden dilakukan berdasarkan porpusive sampling. Sementara teknik pengolahan dan analisis data menggunakan analisis deskriptif dan teknik rentang kriteria serta metode pembobotan paired comperasion. Analisis pengukuran balanced scorecard di bagi dalam 4 (empat) perspektif, yaitu perspektif keuangan, pelanggan, bisnis internal serta pertumbuhan dan pembelajaran.

Untuk melakukan analisis dari data-data yang sudah terkumpul dari hasil penelitian, kemudian dilakukan pengelolaan secara bertahap, di antaranya: (1) Editing, yaitu untuk tahap awal dilakukan persiapan melalui pengecekan data-data yang sudah terkumpul di lapangan, apakah telah memenuhi semua sumber-sumber yang dibutuhkan secara lengkap atau belum. Jawaban-jawaban dari hasil wawancara apakah telah tercakup semua permasalahan yang telah diajukan ataukah belum, (2) Tabulasi, setelah dilakukan pengecekan terhadap data-data yang terkumpul, kemudian untuk langkah selanjutnya diadakan pengklasifikasian data dengan tujuan agar data-data yang dianggap relevan 
dapat digunakan.dan (3) Analisis, untuk tahap terakhir dilakukan analisis data dalam proses pengumpulan data. Analisis yang akan dilakukan terhadap jawaban-jawaban dari responden yang kemudian diinterpretasikan dalam bentuk uraian sehingga diperoleh suatu kesimpulan terhadap permasalahanpermasalahan yang telah ada.

\section{Profil Lembaga Amil Zakat Infaq dan Sadaqoh Masjid Agung (LAZISMA) Jawa Tengah}

Lembaga zakat sebagaimana tercantum dalam UU zakat (Undangundang No.38 tahun 1999 tentang Pengelolaan Zakat) adalah lembaga zakat yang dibentuk oleh masyarakat. Lembaga-lembaga ini bisa lingkup operasinya tingkat regional maupun nasional. Lembaga yang dibentuk oleh Badan Pengelola Masjid Agung Jawa Tengah ini akan mengembangkan dan mengoptimalkan sumber daya yang ada dengan memadukan professional quality dan moral quality dalam sebuah proses system manajemen, pendidikan, riset dan pemberdayaan secara integral dan komprehensif. Inilah arti pentingnya berdirinya LAZISMA. ${ }^{14}$

Visi LAZISMA yaitu mewujudkan pengelolaan zakat, infaq dan shadaqah yang professional, kuat dan terpercaya. Misi LAZISMA yaitu :

1) Membantu meringankan penderitaan masyarakat dengan memberikan pelayanan, informasi, edukasi dan pemberdayaan.

2) Menjadi mediator dan fasilitator antara dermawan (aghniya) dan fakir miskin (dh'afa) melalui zakat, infaq, shadaqah, waqaf dan dana kemanusiaan lainnya.

3) Mengumpulkan, mendistribusikan dan mendayagunakan zakat, infaq dan shadaqah sesuai dengan ketentuan agama dan peraturan perundangundangan yang berlaku.

\footnotetext{
${ }^{14}$ Dikutip dari: Sejarah singkat Lembaga Amil Zakat Infaq dan Shadaqah Masjid Agung (LAZISMA) Jawa Tengah, Semarang, 7 Agustus 2005.
} 
Pendekatan Balance Scorecard pada LAZISMA

\section{Aktivitas Lembaga Amil Zakat Infaq dan Shadaqah (LAZISMA) Jawa Tengah}

Untuk merealisasikan visi dan misi di atas, LAZISMA mempunyai tiga strategi pemberdayaan yaitu:

1) Penghimpunan Dana dan Bantuan Masyarakat

a) Dana Khusus bencana kemanusiaan

b) Pakaian, bahan makanan (sembako) dan obat-obatan

c) Hewan qurban

2) Bantuan Kemanusiaan
a) Daerah-daerah konflik (Maluku, Maluku utara, Poso, Aceh, dll)
b) Daerah-daerah bencana alam
c) Daerah kritis dan minus

3) Pembangunan Masyarakat
a) Bina desa miskin dan tertinggal
b) Pemberdayaan ekonomi ummat
c) Pendidikan alternatif
d) Pembangunan pelayanan kesehatan mandiri
e) Distribusi hewan qurban

\section{Program LAZISMA Jawa Tengah}

1) Pendidikan

a. Beasiswa dan pembinaan bagi siswa SD/MI dan SMP/MTS yang tidak mampu

b. Pendidikan alternatif dengan biaya gratis dan berkualitas yang diperuntukkan bagi anak-anak pengungsi, korban bencana, yatim dan dhu'afa

2) Pelatihan

a. Pelatihan Fiqih dan manajemen zakat 
b. Pelatihan strategi fundraising (Zakat Infaq dan Shadaqah) ZIS

c. Pelatihan Public Relation lembaga ZIS

d. Pelatihan akuntansi dan manajemen keuangan lembaga ZIS

e. Pelatihan Total Quality Management (TQM) lembaga ZIS

3) Pengembangan
a. Pendirian dan pengembangan lembaga ZIS
b. Kompilasi (penyusunan laporan keuangan)
c. Penyusunan Sistem Informasi Manajemen (SIM)
d. Kompeterisasi sistem Informasi
e. Penyusunan panduan kebijakan pengelolaan ZIS yang sesuai syariah Islam

4) Riset
a. Pengkajian Aspek syari'ah dalam pengelolaan ZIS
b. Pengkajian kebijakan peraturan-peraturan pengelolaan zakat
c. Riset pengembangan produk

5) Publikasi
a. Penerbitan Buletin
b. Penerbitan Buku
c. Penerbitan Jurnal

6) Dakwah Sosial

a. Pengajian Reguler lepas kerja bagi para eksekutif dan kaum professional

b. Penberdayaan desa-desa miskin, baik aspek rohani, pembangunan fasilitas umum dan peningkatan ekonomi masyarakat

c. Pemberdayaan ekonomi usaha kecil melalui kelompok swadaya masyarakat, seperti kelompok petani gurem, peternak, pengrajin, pedagang kecil, tukang objek dan nelayan.

d. Bantuan kemanusiaan bagi daerah-daerah korban bencana alam berupa pelayanan kesehatan, obat-obatan, makanan, pakaian dan lain-lain. 
Pendekatan Balance Scorecard pada LAZISMA

e. Pelayanan kesehatan masyarakat dengan biaya murah dan terjangkau, seperti penyediaan klinik-klinik kesehatan di daerah miskin dan kurang terjangkau. ${ }^{15}$

\section{Mekanisme Kerja Lembaga Amil Zakat Infaq dan Shadaqah Masjid Agung (LAZISMA)}

LAZISMA berada di bawah naungan Ketakmiran Masjid Agung Jawa Tengah. LAZISMA dibentuk setelah dikeluarkannya Surat Keputusan Badan Pengelola Masjid Agung Jawa Tengah Nomor 10.KEP/BPMAJT/VIII/2005 Tentang Pengelolaan LAZISMA diharapkan mampu mengembangkan dan mengoptimalkan sumber daya yang ada dengan memadukan profesional quality dan moral quality dalam sebuah proses manajemen, pendidikan, riset dan pemberdayaan secara integral dan komprehensif.

Dalam melaksanakan tugas sebagai amil zakat, sistem kinerja LAZISMA Jawa Tengah terstruktur dalam suatu hirarki tanggung jawab sesuai dengan job dan tugas pengurus yang telah ditunjuk, tetapi untuk pelaksana tugas harian diangkat karyawan/staf LAZISMA.

\section{Sumber Dana Zakat Untuk Usaha Produktif Lembaga Amil Zakat Infaq dan Shadaqah Masjid Agung (LAZISMA) Jawa Tengah}

LAZISMA Jawa Tengah mengelola dan mengembangkan dana zakat untuk usaha produktif yaitu dengan misi usaha produktif, maksudnya adalah untuk peningkatan ibadah dan peningkatan perekonomian umat Islam dengan berbasis masjid. Dalam pengelolaan dan pengembangan usaha produktif LAZISMA menggunakan sistem kejamaahan, dimana jamaah pengajian di masjid yang anggotanya mempunyai usaha, maka LAZISMA memberikan dana kepada mereka. ${ }^{16}$ Lembaga Amil Zakat Infaq dan Shadaqah Masjid Agung (LAZISMA) Jawa Tengah penghimpunan dananya yaitu menggunakan sistem sebagai berikut:

15 Dikutip dari : Sejarah singkat Lembaga Amil Zakat Infaq dan Shadaqah Masjid Agung (LAZISMA) Jawa Tengah, Semarang, 7 Agustus 2005.

16 Hasil Wawancara dengan Staf LAZISMA Jawa Tengah (Sdr Murni), di Kantor LAZISMA Jawa Tengah, hari Rabu 16 Oktober 2013 
1. Sistem penghimpunan dana dari kotak infaq LAZISMA Yaitu penghimpunan dana dengan sasarannya kepada para pedagang di daerah Masjid Agung Jawa Tengah dan para Pedagang Kaki Lima (PKL) di lingkup Masjid Agung Jawa Tengah, dengan memasang kotak-kotak kecil atau kotak infaq LAZISMA seperti di Menara Masjid Agung (di depan pintu masuk Masjid Agung), di toko-toko souvenir, di hotel Masjid Agung dan lain-lain.

2. Sistem penghimpunan dana secara langsung kepada para muzakki. Sistem penghimpunan dana secara langsung kepada para muzakeki di sini ada dua macam cara yaitu yang pertama dengan membawa surat permohonan dari LAZISMA yang diberikan kepada para muzakki tetap (muzakki yang sering berzakat di LAZISMA) Cara yang kedua yaitu dengan melalui telepon memberitahukan kepada para muzakki yang ingin berzakat di LAZISMA. ${ }^{17}$

\section{Pelaksanaan Pendayagunaan Zakat Untuk Usaha Produktif Lembaga Amil Zakat Infaq dan Shadaqah Masjid Agung (LAZISMA) Jawa Tengah.}

Zakat mal adalah salah satu program pendayagunaan zakat untuk usaha produktif yang dilakukan LAZISMA Jawa Tengah yaitu Dana Produktif. Maksud dari dana produktif ini adalah dana yang berkembang atau bisa untuk modal usaha. Sasaran dana produktif ini diberikan kepada jamaah pengajian di masjid. Pada umumnya setiap anggota jamaah masjid tersebut sudah mempunyai usaha kecil sampai dengan menengah (usaha menengah ke bawah) seperti usaha warung makan dan minuman yang mereka mempunyai modal sedikit (modalnya kecil) dan masih memerlukan tambahan modal. Bagi mereka yang belum mempunyai pekerjaan dan mereka ingin membuka usaha dagang (usahanya menengah kebawah) dapat mengajukan permohonan ke LAZISMA. ${ }^{18}$ Setiap koordinator jamaah masjid yang mengajukan permohonan tambahan modal tersebut harus memberikan laporan kepada LAZISMA, siapa saja yang nantinya akan diberikan tambahan modal atau dana produktif LAZISMA.

$17 \mathrm{ibid}$

$18 \mathrm{ibid}$ 
Pendekatan Balance Scorecard pada LAZISMA

Sebelum LAZISMA memberikan dana produktif, LAZISMA mensurvey jenis usaha dari jamaah masjid tersebut yang sekiranya sesuai dengan kriteria atau bisa memenuhi beberapa persyaratan, termasuk kemampuan mereka dalam mengelola dan mengembangkan usahanya tersebut dengan baik. Setiap satu koordinator jamaah masjid tersebut bertanggung jawab atas semua anggotanya dalam mengelola dan mengembangkan usahanya dan setiap bulannya koordinator tersebut menyetorkan pembayaran angsuran infaq wajib kepada LAZISMA.

Di dalam lingkup Masjid Agung Jawa Tengah sendiri terbagi atas 4 (empat) blok yang digunakan untuk usaha yaitu para Pedagang Kaki Lima (PKL) Blok A, Blok B, Blok C, Blok D. Pedagang Kaki Lima (PKL) yang ada di Blok A dan Blok C jenis usahanya tergolong masih usaha kecil sampai dengan menengah (menengah ke bawah), jenis usahanya seperti padagang bakso, mie ayam, minuman dan makanan ringan, warung-warung makan dan lain-lain, yang tempat usahanya masih berupa tenda-tenda belum berupa bangunan permanen dan mereka (para PKL) menyewa tempat usaha di Masjid Agung biayanya sekitar satu juta rupiah ke bawah tiap tahunnya. Di setiap blok-blok tersebut ada satu koordinator yang bertanggung jawab penuh dalam pengelolaan dan pengembangan usaha. ${ }^{19}$ LAZISMA juga memberikan pinjaman dana produktif kepada mereka memiliki usaha di bidang jasa seperti usaha bengkel dan setel palek dan juga servis sepatu. ${ }^{20}$

LAZISMA hanya memberikan pinjaman dana produktif kepada Pedagang Kaki Lima (PKL) yang ada di Blok A dan Blok C karena mereka masih memerlukan tambahan modal dalam usahanya. Besarnya pinjaman variatif, disesuaikan dengan kemampuan LAZISMA dan kondisi Mustabiqnya, ada yang mendapatkan Rp 500.000-Rp 750.000 yang akan di angsur selama sepuluh bulan. Sifat pinjaman dana produktif ini tanpa ada bunga, namun penerima bantuan pinjaman tersebut dianjurkan memberi infaq sunah kepada LAZISMA yang besarnya tidak ditentukan (tergantung keikhlasan yang bersangkutan).

\footnotetext{
${ }^{19}$ Hasil Wawancara dengan Staf LAZISMA Jawa Tengah (Sdr Murni), di Kantor LAZISMA Jawa Tengah, hari Rabu 16 Oktober 2013 20 ibid
} 
Harapan dari salah seorang penerima bantuan pinjaman tersebut agar LAZISMA selalu meningkatkan bantuan pinjaman pada tahun-tahun berikutnya. Di samping itu diharapkan agar LAZISMA membantu memfasilitasi sarana/tempat usaha yang bersifat permanen atau semi permanen. ${ }^{21}$ Apabila para pedagang yang mendapatkan bantuan pinjaman dana produktif dari LAZISMA sebagai tambahan modal usaha dapat mengembalikan infaq wajib dengan lancar melalui koordinator masing-masing maka para pedagang dapat melakukan perpanjangan pinjaman untuk tambahan modal usaha mereka.

Sedangkan peminjaman dana produktif di luar lingkup Masjid Agung Jawa Tengah seperti di daerah Banyumanik, Morodemak, Bangetayu, Sambiroto dan lain-lain didalam mengembalikan infaq wajib di serahkan kepada satu koordinator masjid (koordinator dari jamaah masjid). Koordinator tersebut tiap bulannya menyetorkan infaq wajib kepada LAZISMA, biasanya dilakukan setiap tanggal 25 atau akhir bulan, sesuai dengan yang sudah ditetapkan dalam BAP (Berita Acara Pembayaran). Khusus di daerah Morodemak dalam pengembalian infaq wajib oleh koordinatornya dilakukan setahun sekali karena daerah Morodemak jaraknya agak jauh dengan LAZISMA. ${ }^{22}$

LAZISMA melalui dana zakat untuk usaha produktif juga membuat program Bina Desa Miskin. Program Bina Desa Miskin di mulai tahun 2005 yang meliputi daerah Moredemak, Banyumanik, Bangetayu. LAZISMA dalam mendayagunakan zakat untuk usaha produktif yaitu melalui prosedur yang jelas. Prosedur yang dimaksud adalah: Studi kelayakan-Menetapkan jenis usaha-Melakukan bimbingan dan penyuluhan-Melakukan pemantauan, pengendalian dan pengawasan -Mengadakan evaluasi-Membuat laporan. ${ }^{23}$

\footnotetext{
${ }^{21}$ Hasil Wawancara Dengan Sdr Nur Sa'adaah, Salah Satu Pedagang Kaki Lima (PKL) Blok C Lingkup Masjid Agung Jawa Tengah, Hari Rabu 16 Oktober 2013. kata "KAMI" disini adalah para Pedagang Kaki Lima (PKL) Blok C MAsjid Agung Jawa Tengah.

22 Hasil Wawancara dengan Staf LAZISMA Jawa Tengah (Sdr Murni), di Kantor LAZISMA Jawa Tengah, Hari Rabu 16 Oktober 2013 23 ibid
} 
Pendekatan Balance Scorecard pada LAZISMA

\section{Program dan Sasaran Zakat, Infaq dan Shadaqah (ZIS) Lembaga Amil zakat Infaq dan Shadaqah Masjid Agung (LAZISMA) Jawa Tengah}

Program dan sasaran zakat, infaq dan shadaqah (ZIS) yang telah di jalankan LAZISMA Jawa Tengah adalah sebagai berikut: 1)Beasiswa Dlu'Afaa', 2)Bantuan Dana Pendidikan, 3) Pendidikan Alternatif Gratis, 4) Santunan Anak Yatim, 5)Distribusi Hewan Qurban, 6) Pemberdayaan Ekonomi Usaha Kecil, 7)Bina Desa Miskin, dan 8) Bantuan Kemanusiaan

\section{Situasi dan Kondisi Perkembangan Penghimpunan dan Pendayagunaan Zakat Untuk Usaha Produktif LAZISMA Jawa Tengah}

Sejauh ini perkembangan penghimpunan dan pendayagunaan zakat bagi usaha produktif di LAZISMA Jawa Tengah secara umum perkembangannya sangat baik, namun untuk penghimpunan dana LAZISMA masih terbatas dari para muzakki di wilayah kota Semarang, baik dari Jamaah Masjid, Pejabat Pemerintah Provinsi Jawa Tengah, Anggota Legislatif, Pejabat Pemerintahan Kota (PEMKOT) Semarang, para Pengusaha dan lain-lain, tetapi belum sampai mencakup muzakki dari wilayah lain (luar daerah Semarang). Sedangkan untuk pendayagunaannya semakin banyak mustabiq yang menerima dana bergulir untuk usaha produktif, baik para Pedagang Kaki Lima (PKL) di lingkungan Masjid Agung Jawa Tengah sendiri maupun di luar Masjid Agung, seperti para mustabiq di Banyumanik, Morodemak, Bangetayu, Sambiroto dan lain-lain. ${ }^{24}$ Selama ini kendala yang dihadapi tidak ada yang berarti, semua berjalan dengan baik setelah dirapatkan oleh pengurus melalui Rapat Pengurus LAZISMA terlebih dahulu, sehingga hasil kebijaksanaan dan hasil rapatpun dilaksanakan sesuai dengan rencana.

\section{Analisis Balance Scorecard pada Lembaga Amil Zakat (LAZ)}

Dari ketiga lembaga amil zakat yang diteliti dapat dibuat analisis perbandingan dari perspektif keuangan, pelanggan, bisnis internal dan perspektif pertumbuhan dan pembelajaran dengan memberikan score pada

${ }^{24}$ Hasil Wawancara dengan Asisten Direktur II LAZISMA Jawa Tengah, Hari Jumat 18 Oktober 2013 
masing-masing lembaga tersebut. Data Dana ZIS yang dihimpun dan disalurkan, Jumlah Mustahik dan Muzakki dan jumlah karyawan dari LAZISNU, LAZISMU dan LAZISMA Jawa Tengah dapat dilihat pada tabel 4.1. dibawah ini:

Tabel 4.1. Data Umum LAZIMA

\begin{tabular}{|l|c|c|c|}
\hline \multirow{2}{*}{ Keterangan } & \multicolumn{3}{|c|}{ TAHUN } \\
\cline { 2 - 4 } & \multicolumn{1}{|c|}{$\mathbf{2 0 1 1}$} & $\mathbf{2 0 1 2}$ & $\mathbf{2 0 1 3}$ \\
\hline Jumlah Aset LAZ & - & - & - \\
\hline $\begin{array}{l}\text { Dana ZIS Yang } \\
\text { terkumpul }\end{array}$ & $\begin{array}{l}\text { Rp. } \\
458.967 .780,00\end{array}$ & Rp. 625.416.932,00 & $\begin{array}{c}\text { Rp. } \\
1.001 .897 .785,00\end{array}$ \\
\hline $\begin{array}{l}\text { Dana ZIS Yang } \\
\text { di salurkan }\end{array}$ & $\begin{array}{l}\text { Rp. } \\
344.225 .835,00\end{array}$ & Rp. 469.062.699,00 & $\begin{array}{c}\text { Rp. } \\
751.423 .339,00\end{array}$ \\
\hline Jumlah Mustahik & 232 & 333 & 335 \\
\hline Jumlah Muzakki & 125 & 145 & 260 \\
\hline $\begin{array}{l}\text { Jumlah Karyawan } \\
\text { LAZ }\end{array}$ & 1 & 1 & 1 \\
\hline
\end{tabular}

Sumber: Data primer diolah, 2013

\section{Perspektif Keuangan}

Penilaian perspektif keuangan pada LAZISMA Jawa Tengah menunjukkan bahwa data penerimaan dan penyaluran dana ZIS pada LAZISMA periode 2011-2012 mengalami kenaikan sebesar 27\% (Rp. 166.449.152) dari Rp. 458.967.780 pada tahun 2011 menjadi Rp. 625.416.932 pada tahun 2012 dan meningkat 38\% (Rp 376.480.853) dari Rp. Rp. 625.416.932 pada tahun 2012 menjadi Rp. 1.001.897.785 pada periode tahun 2013. Dalam hal ini terjadi kenaikan jumlah penerimaan dan penyaluran dana ZIS yang cukup tinggi pada LAZISMA Jawa Tengah. Penyaluran dana ZIS pada LAZISMA Jateng tidak menghabiskan seluruh dana ZIS yang sudah diterima namun mengelolanya sedemikian rupa supaya dapat memberikan manfaat yang optimal bagi mustahik. Lembaga Amil Zakat Infaq dan Shadaqah Masjid Agung (LAZISMA) Jawa Tengah telah melaksanakan program kerjanya dengan baik, sasaran strategis keuangan dan target 
Pendekatan Balance Scorecard pada LAZISMA

pencapaian dana Zakat infak dan Shodaqoh juga tercapai dengan baik. Pengumpulan dana ZIS dilakukan secara proaktif dan sosialisasi ZIS juga dilakukan secara kontinyu bahkan setiap hari jumat LAZISMA membuka stand di MAJT untuk menerima dana ZIS yang akan disumbangkan oleh jamaah MAJT.

Sedangkan untuk penyaluran dana yang dilakukan oleh LAZISMA Jawa Tengah juga dilaksanakan sesuai dengan sasarannya yaitu program pendayagunaan zakat untuk usaha produktif yang disebut dengan Dana Produktif. Dana produktif adalah dana yang berkembang atau bisa untuk modal usaha. Sasaran dana produktif ini diberikan kepada jamaah pengajian di masjid. Pada umumnya setiap anggota jamaah masjid tersebut sudah mempunyai usaha kecil sampai dengan menengah (usaha menengah ke bawah) seperti usaha warung makan dan minuman yang mereka mempunyai modal sedikit (modalnya kecil) dan masih memerlukan tambahan modal. Bagi mereka yang belum mempunyai pekerjaan dan mereka ingin membuka usaha dagang (usahanya menengah kebawah) dapat mengajukan permohonan ke LAZISMA.Sifat pinjaman dana produktif ini tanpa ada bunga, namun penerima bantuan pinjaman tersebut dianjurkan memberi infaq sunah kepada LAZISMA yang besarnya tidak ditentukan (tergantung keikhlasan yang bersangkutan). Sedangkan sasaran penerima dana ZIS dilakukan secara selektif melalui rapat pengurus LAZISMA yang akan menentukan obyek (siapa) calon penerima bantuan pinjaman dana produktif dan nominal rupiah yang akan di terima masing-masing calon peminjam. LAZISMA melalui dana zakat untuk usaha produktif juga membuat program Bina Desa Miskin.

\section{Perspektif Pelanggan}

Pengukuran perspektif pelanggan didasarkan pada kepuasan pelanggan dalam menerima pelayanan dari lembaga. Kelompok yang dilibatkan dalam kepuasan pelanggan adalah mustahik. Pelanggan LAZISMA Jawa Tengah menunjukkan kepuasan atas penerimaan pelayanan dari LAZISMA Jawa Tengah. Dana produktif yang disalurkan dengan tepat sasaran sangat membantu dalam pemberdayaan ekonomi masyarakat kurang mampu yang mendapatkannya. Disamping itu ada program pendampingan yang akan 
membimbing mereka dalam melaksanakan usahanya sehingga diharapkan dapat meningkatkan taraf hidup mustahik dan nantinya para mustahik akan bisa menjadi muzakki. Data muzakki LAZISMA Jawa Tengah pada periode 2011-2013 menunjukkan adanya peningkatan yang cukup menggembirakan. Jumlah muzakki pada tahun 2011 sebanyak 125 muzakki tumbuh menjadi 125 muzakki pada tahun 2012 dan meningkat pesat menjadi 260 muzakki pada periode tahun 2013 .

Program dan sasaran zakat, infaq dan shadaqah (ZIS) yang telah di jalankan LAZISMA Jawa Tengah adalah Beasiswa Du'Afaa', Bantuan Dana Pendidikan, Pendidikan Alternatif Gratis, Santunan Anak Yatim, Distribusi Hewan Qurban, Pemberdayaan Ekonomi Usaha Kecil, Bina Desa Miskin dan Bantuan Kemanusiaan juga sangat membantu masyarakat. LAZISMA Jateng mengalokasikan cadangan dana ZIS 25\% untuk didistribusikan pada dana produktif dalam rangka pemberdayaan ekonomi umat. Hal ini pula yang manjadikan muzakki termotivasi untuk menyalurkan dana ZISnya melalui LAZISMA Jateng dengan harapan dapat ikut berkontribusi dalam pemberdayaan ekonomi umat dan meningkatkan taraf hidup masyarakat disekitarnya.

\section{Perspektif Bisnis Internal}

Pengukuran perspektif proses bisnis internal didasarkan sejauh mana aktivitas pada lembaga dapat dijalankan untuk memenuhi keinginan dan kebutuhan pelanggan (stakeholders). Pengukuan perspektif ini digunakan indeks organisasi yang dikemukakan oleh Urlich (1999) yang meliputi pembelajaran, kemampuan untuk berubah, penanganan keluhan pelanggan, waktu yang diperlukan untuk menangani keluhan dan akuntabilitas organisasi. LAZISMA Jawa Tengah dijalankan sesuai dengan prosedur yang telah ditetapkan dan diharapkan telah mengakomodir kepentingan stakeholder (Pengurus MAJT, Muzakki, Mustahik dan masyarakat). Standar yang digunakan dalam pengelolaan ZIS juga telah disosialisasikan dengan berbagai cara. 
Pendekatan Balance Scorecard pada LAZISMA

\section{Perspektif Pertumbuhan dan Pembelajaran}

Perspektif pertumbuhan dan pembelajaran didasarkan pada pertumbuhan dan pembelajaran SDM (karyawan) dalam menghadapi perubahan-perubahan dimasa yang akan datang. Pengukuran perpsektif ini didasarkan pada kepuasan karyawan sebagai human capital bagi organisasi dalam aspek: cakupan kerja strategis, produktivitas, retensi dan ketersediaan sistem informasi. Jumlah karyawan pada LAZISMA Jateng ternyata hanya satu orang. Sangat minimnya SDM pada organisasi pengelolaan ZIS ini menimbulkan tidak mampunya organisasi dalam melaksanakan fungsifungsinya secara maksimal.

Dalam kuesioner yang dibagikan kepada karyawan LAZ diketahui bahwa pada LAZISMA Jawa Tengah menunjukkan bahwa karyawan merasa ikut terlibat dalam pengambilan keputusan LAZ, bisa bekerjasama dengan baik dengan pimpinan, tidak hanya berorientasi gaji, mendapatkan fasilitas, penghargaan dan dapat berkomunikasi dengan baik. Perspektif pertumbuhan dan pembelajaran pada SDM masih dirasa kurang mencukupi. Jumlah karyawan LAZISMA Jawa Tengah yang merupakan karyawan tetap hanya satu orang. Namun karena sistem organisasinya sudah cukup baik maka kegiatan operasional pada LAZISMA Jawa Tengah dapat berjalan dengan baik.

Karyawan pada lembaga zakat ini cenderung karyawan yang loyal, bukan semata-mata untuk mencari pendapatan namun lebih karena keinginan untuk beribadah kepada Allah SWT. Hal inilah yang menyebabkan mereka tetap bekerja dengan baik dan sepenuh hati walaupun jumlah pendapatannya tidak seberapa. Pengetahuan mengenai pengelolaan ZIS biasanya diperoleh dari pelatihan-pelatihan, belajar sendiri secara otodidak dan mempelajari sistem yang telah digunakan dalam organisasi tersebut.

\section{Kesimpulan}

Berdasarkan pengolahan data dan hasil analisis Badan Amil Zakat (BAZ) dengan mengacu pada permasalahan dan tujuan penelitian ini, maka dapat disimpulkan bahwa: 
1. Pengelolaan zakat pada LAZISMA MAJT yang diteliti berdasarkan Balance Scorecard secara umum belum cukup baik. Tidak maksimalnya pengelolaan zakat pada ketiga lembaga tersebut karena lembaga tersebut adalah organisasi sosial kemasyarakatan Islam yang tidak berorientasi pada profit.

2. Hambatan Pengelolaan ZIS lebih pada kurangnya SDM pada LAZISMA Jateng yang hanya memiliki seorang karyawan sehingga tidak dapat melaksanakan fungsi-fungsi manajemen dengan optimal.

3. Implementasi balanced scorecard dalam rangka revitalisasi Lembaga Pengelola Zakat menunju Good Organzation Governance pada LAZISMA Jawa Tengah belum dilaksanakan secara maksimal khususnya dalam perspektif keuangan. Sedangkan dari perspektif pelanggan yang didasarkan pada kepuasan pelanggan dalam menerima pelayanan dari lembaga cenderung baik karena sebagai organisasi sosial kemasyarakatan yang berdasarkan Islam mereka memperlakukan mustahik sebagai keluarga. Perspektif bisnis internal yang meliputi pembelajaran, kemampuan untuk berubah, penanganan keluhan pelanggan, waktu yang diperlukan untuk menangani keluhan dan akuntabilitas organisasi juga dirasakan kurang karena bukan berorientasi profit, melainkan untuk kepentingan ibadah. Perspektif pertumbuhan dan pembelajaran didasarkan pada pertumbuhan dan pembelajaran SDM (karyawan) didasarkan pada kepuasan karyawan sebagai human capital bagi organisasi menunjukkan bahwa karyawan yang dimiliki oleh lembaga zakat tersebut relatif masih dilandasi oleh faktor ibadah, loyalitas yang ditunjukkan oleh karyawan dan usaha untuk belajar secara otodidak dilandasi untuk ibadah dan mencari ridha Allah SWT semata.

4. Strategi yang digunakan pada LAZISMA Jateng:

a. Penghimpunan dana kurang optimal, diperlukan strategi jemput bola dengan menjalin kemitraan misalnya menggunakan mailing, silaturahmin, atau media lainnya yang dapat digunakan dalam rangka menjalin kemitraan antara LAZISMA dengan mitra.

b. Masalah penyaluran, dana LAZISMA sudah cukup baik karena tidak hanya digunakan untuk konsumtif namun juga disalurkan pada sektor produktif walaupun masih terbatas hanya pada 8 asnaf. 
Pendekatan Balance Scorecard pada LAZISMA

c. Untuk Binis Internal perlu dikembangkan profesionalisme lembaga dan merubah menset pengelola, bahwa lembaga yang non profit juga memerlukan pengembangan dan pengelolaan secara profesional.

d.Perspektif pertumbuhan dan pembelajaran, dalam hal ini laziz harus mengembangkan SDM untuk memfungsikan fungsi-fungsi manajemen pada lembaga. Selama ini pengelolaan laz dari pengumpulan, pendistribusian hanya ditangani oleh 1 orang karyawan, sehingga fungsifungsi manajemen pada LAZISMA kurang berjalan efektif.

e. Perlu ditingkatkan kemampuan karyawan dalam pengelolaan laz melalui pendidikan dan pelatihan, sehingga pengelolaan laz perlu mengalokasikan dana untuk pengembangan SDM.

\section{Saran}

1. Bagi LAZISMA Jateng diharapkan dapat meningkatkan sosialisasi dan edukasi tentang zakat kepada masyarakat Jawa Tengah sehingga dapat memaksimalkan penghimpunan dana zakat sehingga bisa menjadi solusi dalam pengentasan kemiskinan.

2. Meningkatkan profesionalisme pengelolaan dana LAZISMA baik dari sisi keuangan ataupun non keuangan

3. Diadakan pelatihan untuk membekali SDM pada LAZISMA Jateng 


\section{DAFTAR PUSTAKA}

Ahmed, Salehuddin, "Empowering local communities: Comilla Approach and Experiences", dalam Joseph Mullen (Ed.), Rural Poverty, Empowerment And Sustainable Livelihoods, England: Asghate Publishing Ltd, 1999.

Ahmad Thib Raya, Hj. Siti Musdah Mulia, Menyelami Seluk-beluk Ibadah Dalam Islam, Cet.3, Jakarta: Kencana, 2003

Ali Mutasowifin, 2002, Penerapan balanced scorecard sebagai tolok ukur Penilaian Pada Badan Usaha Berbentuk Koperasi, Jurnal Universitas Paramadina, Vol. 1 No. 3, Mei 2002: 245-264.

Amiruddin, Pemprof Sulsel dan IAIN Raden Patah Palembang, Anatomi Fiqh Zakat Potret Dan Pemahaman BAZ Sulsel, Yogyakarta: Pustaka Pelajar, 2005

Anthony, Robert N. 1999. Management Control in Nonprofit Organizations. $6^{\text {th }}$ edition. Boston, Massachusetts: Irwin/ McGraw-Hill.

Asep Saepudin Jahar, Masa Depan Filantropi Islam Indonesia Kajian Lembaga-lembaga Zakat dan Wakaf, Makalah disampaikan dalam acara Annual Conference on Islamic Studies (ACIS) ke 10 di Banjarmasin, 1 - 4 November 2010, Kalimantan Selatan, 685.

Baidi, Yasin, Zakat dan Perubahan Sosial: Telaab terhadap Interpretasi dan Mekanisme Alokasi Dana Zakat oleh Rumah Zakat Indonesia DSUQ (RSI-DSUQ) Yogyakarta, Tesis Program Pascasarjana IAIN Sunan Kalijaga Yogyakarta 2005, Tidak Diterbitkan.

Departemen Agama RI, Al Quran dan Terjemahnya, Semarang: Toha Putra, 1999

Didin Hafidhuddin, Zakat Dalam Perekonomian Modern, Jakarta: Gema Insani, 2002

Gaspersz, Vincent (2003), Sistem Manajemen Terintegrasi: Balanced Scorecard dengan Six Sigma untuk Organisasi Bisnis dan Pemerintah, Jakarta, Gramedia.

Heri Sudarsono, Bank dan Lembaga Keuangan Syariah Deskripsi dan Ilustrasi, Yogyakarta : EKONISIA, cet.2, 2004

Huda, M. Shofiyul, Politik. Hukum Indonesia (Telaah terhadap UU No. 38/1999 tentang Pengelolaan Zakat, Tesis Program Pascasarjana IAIN Sunan Kalijaga Yogyakarta 2002, Tidak Diterbitkan. 
Pendekatan Balance Scorecard pada LAZISMA

Imam Abi Abdillah Muhammad, Shakbih Bukhari Juz II, Semarang; PT Thoha Putra, t,th

Imam Muslim, Sbakbih Muslim Juz I, Semarang; Thoha Putra, t,th Imam Muslim, Shakbih Muslim Juг I, Semarang; Thoha Putra, t,th

Kaplan, Robert S dan David P. Norton, 1996, Balanced Scorecard: Translating Strategy Into Action ${ }_{2}$ Boston: Havard Business School Press.

M. Abu Zahra, Membangun Masyarakat Islam, Jakarta: Pustaka Firdaus, hlm: 152

M. Daud Ali dan Habibah, Lembaga-Lembaga Islam di Indonesia, Jakarta; Raja Grafindo Persada, 1995.

Murni (Staf LAZISMA Jawa Tengah), Hasil Wawancara di Kantor LAZISMA Jawa Tengah, hari Sabtu 21 Juni 2008

Mursyidi, Akuntansi Zakat Kontemporer, Bandung; Remaja Grafindo Rosda Karya, 2003

Nasrun Haroen, Usbul Fiqh1, Jakarta: PT Logos Wacana Ilmu, 1997

Nur Sa'adaah, (Salah Satu Pedagang Kaki Lima (PKL) Blok C Lingkup Masjid Agung Jawa Tengah), Hasil Wawancara pada Hari Sabtu 5 Juli 2008.

Pusat Pembinaan dan Pengembangan Bahasa, Kamus Besar Bahasa Indonesia, Cet. 3,Jakarta: Balai Pustaka, 1990

Qadir, Abdurahman, Pembaharuan Hukum Islam: Studi Pemikiran Yusuf alQaradhawi tentang Zakat Profesi, Tesis Program Pascasarjana IAIN Syarif Hidayatullah Jakarta 1990, Tidak Diterbitkan.

Qurratulaini, Intan, Pemberdayaan Umat Melalui Pendayagunaan Dana Zakat Pada Lazis UII Yogyakarta, Tesis Program Pascasarjana IAIN Sunan Kalijaga Yogyakarta 2006, Tidak Diterbitkan.

Sabiq, Sayyid, Figh al-Sunnah, Cet. V, Jilid I, Beirut: Dar al-Fikr, 1982.

Salahuddin, M., Zakat dan Pemberdayaan Ekonomi Umat (Studi Pengelolaan Zakat di $B A Z D A$ Kab. Bima, Tesis Program Pascasarjana IAIN Sunan Kalijaga Yogyakarta 2002, Tidak Diterbitkan.

Salima, Siti, Zakat: Sarana Pengentasan Kemiskinan (Sarana Kasus Pengelolaan Zakat di BAZ Kab. Lumajang), Tesis Program Pascasarjana IAIN Sunan Kalijaga Yogyakarta 2003, Tidak Diterbitkan.Sofyan Effendi, "Prinsipprinsip Analisa Data", dalam Misri Singarimbun, Metode Penelitian Survei, Jakarta: LP3ES, 1988 
Ari Kristin Prseryoningrum

Sejarah singkat Lembaga Amil Zakat Infaq dan Shadaqah Masjid Agung (LAZISMA) Jawa Tengah, Semarang, 7 Agustus 2005.

Surat Keputusan Ketua Badan Pengelola Masjid Agung jawa Tengah Nomor : 10/KEP/BPMAJT/VIII/2005, Tentang Pengelola Lembaga Amil Zakat, Infaq dan Shadaqah Masjid Agung (LAZISMA) Jawa Tengah Syaudi Ismail Situnggal, Penerapan Zakat Dalam Dunia Modal, (Jakarta: Pustaka Dian, 1987)

Wahbah Al-Zuhayly, Al Figh Al Islami Wa'adillah, Terjemah: Agus Effendi dan Bahruddin Fannany, Zakat Kajian Berbagai Maz̧bab, Bandung: PT Remaja Rosdakarya, Cet. 1, 1995 
Pendekatan Balance Scorecard pada LAZISMA 